\title{
Chromogranin Negative
}

National Cancer Institute

\section{Source}

National Cancer Institute. Chromogranin Negative. NCI Thesaurus. Code C153223.

An indication that the expression of chromogranin family proteins have not been detected in a sample, 